\title{
Impact of soil application with humic acid and foliar spray of milagro bio-stimulant on vegetative growth and mineral nutrient uptake of Nonpareil almond young trees under Nubaria conditions
}

Mahmoud Sami Abourayya, Nabila Elbadawy Kaseem, Thanaa Shaban Mohamed Mahmoud, Amal Masoad Rakha*, Ramadan Ahmed Eisa and Osama Abdelfattah Amin

\begin{abstract}
Background: At present, agricultural production management techniques focus on greater commitment to environmental sustainability. As such, this study was carried out during two successive seasons (2018 and 2019) to investigate the impact of two natural bio-stimulant substances: humic acid $(H)$ and milagro $(M)$ on vegetative growth and nutritional status of Nonpareil almond young trees grown in Experimental Research Station of National Research Centre, Nubaria, El Behera governorate, Egypt. Three-year-old uniform trees were treated at the beginning of growth season by soil application of humic acid $(\mathrm{H})$ and foliar spray of milagro $(\mathrm{M})$ bio-stimulant. There were ten treatments as follows: control (untreated seedlings), $10 \mathrm{~g}$ humic acid plus $10 \mathrm{ml} / \mathrm{l}$ milagro, $20 \mathrm{~g}$ humic acid plus 10 $\mathrm{ml} / \mathrm{l}$ milagro, $30 \mathrm{~g}$ humic acid plus $10 \mathrm{ml} / \mathrm{l}$ milagro, $10 \mathrm{~g}$ humic acid plus $20 \mathrm{ml} / \mathrm{l}$ milagro, $20 \mathrm{~g}$ humic acid plus $20 \mathrm{ml} /$ I milagro, $30 \mathrm{~g}$ humic acid plus $20 \mathrm{ml} / \mathrm{l}$ milagro, $10 \mathrm{~g}$ humic acid plus $30 \mathrm{ml} / \mathrm{l}$ milagro, $20 \mathrm{~g}$ humic acid plus $30 \mathrm{ml} / \mathrm{l}$ milagro, and $30 \mathrm{~g}$ humic acid plus $30 \mathrm{ml} / \mathrm{l}$ milagro.

Results: The results showed that different treatments improved the vegetative growth of seedlings, stem length, diameter, number of branches and leaves, leaf area, leaf fresh and dry weight, and specific leaf dry weight as well as leaf chlorophylls and minerals content comparing with untreated young trees.

Conclusions: Soil application of $30 \mathrm{~g}$ humic acid along with $30 \mathrm{ml} / \mathrm{l}$ milagro per young tree as foliar spray was the promising treatment as a new fertilization technique that is non-chemical, low-cost, and environmentally safe for improving growth and nutritional status of Nonpareil almond young trees under Nubaria conditions.
\end{abstract}

Keywords: Nonpareil almond, Humic acid, Milagro, Bio-stimulants, Growth, Soil application, Foliar spray

\footnotetext{
* Correspondence: aaaam_am@yahoo.com

Department of Horticultural Crops Technology, Agricultural and Biological Division, National Research Center, 33 El Bohouth St. (Former El-Tahrir St.), Dokki, Giza P.O. 12622, Egypt
}

\section{Springer Open}

(c) The Author(s). 2020 Open Access This article is licensed under a Creative Commons Attribution 4.0 International License, which permits use, sharing, adaptation, distribution and reproduction in any medium or format, as long as you give appropriate credit to the original author(s) and the source, provide a link to the Creative Commons licence, and indicate if changes were made. The images or other third party material in this article are included in the article's Creative Commons licence, unless indicated otherwise in a credit line to the material. If material is not included in the article's Creative Commons licence and your intended use is not permitted by statutory regulation or exceeds the permitted use, you will need to obtain permission directly from the copyright holder. To view a copy of this licence, visit http://creativecommons.org/licenses/by/4.0/. 


\section{Background}

Almond (Prunus amygdalus B. cv. Nonpareil) is a small deciduous tree belonging to the subfamily Prunoideae of the family Rosaceae. Almonds are one of the oldest commercial nut crops of the world; from the Middle and West Asia, it has diffused to other regions and continents which include the Middle East, China, the Mediterranean region, and America (Ladizinsky, 1999). Almond kernels are concentrated sources of energy with a significant share of fat, protein, and fiber. Fats are primarily nonsaturated, mostly oleinic and linoleic fatty acids. Nonsaturated fatty acid is important in maintaining low cholesterol levels in the blood and significant amount of micronutrients (Aslanta et al. 2001). In Egypt, commercial almond production is still limited in spite of suitable environmental conditions for growth and fruiting (Abou Rayya et al. 2009; Kasim et al. 2009).

Humic acid is one of bio-stimulants that are known as the organic substances which promote plant growth and help the trees to withstand harsh environments when applied in small amounts (Chen et al. 1994). It is highly beneficial also for both the trees and the soil, since it maintains proper plant growth as well as it increases nutrient uptake, tolerance to drought and temperature extremes, activity of beneficial soil microorganisms, and availability of soil nutrients particularly in alkaline soils and low organic matter such as newly reclaimed land conditions without excessive use of agricultural chemicals which are considered a menace to the environment (Russo and Berlyn, 1990; Eisa et al., 2016; Abd El-Razek et al. 2018). Uses of humic acid as a soil application improve nutrient availability especially microelements in sandy soils because it promotes nutrient uptake in the form of chelating agent. Moreover, humic substances may increase root growth in a similar manner to auxins (O'Donnell, 1973; Khattab et al. 2012). In addition, the humic acid has many effects as it raises of cation exchange capacity which affects the retention and availability of nutrients, as well as due to a hormonal effect, or a combination of both (Chunhua et al. 1998); as a result, it can be used to solve many problems in soils such as soil nutrient availability and chemical reactions that affect the loss or fixation of almost all nutrients. Generally, there is a growing interest of the use of humic acid and K-humate as a substitute to chemical fertilizers which have potential polluting effects in the environment (Senn and Kingman, 2000).
Milagro is a natural bio-stimulant that extracted from pollen flowers of cabbage (Grove et al. 1979), which is rapid and complete water solubility in water. It has a broad effect on different crops and its impact depends on the time of trans-action. This product is reflecting the effect of auxins, cytokinins, gibberellins, ethylene, and hydrogen sinamed and humic and contains 20\% phosphorus, $10 \%$ potassium, and $3 \%$ boron. It improves plant growth in all parts as a tonic for physiological processes in particular, enhances photosynthesis, increases the yield by $20-25 \%$, and improves quality characteristics (Ebeed et al. 2008; Ramezani and Shekafandeh, 2009; Omaima et al. 2014).

Therefore, the aim of this work was to study the effects of the soil application with humic acid and the foliar spray of milagro on the vegetative growth and mineral nutrient uptake of Nonpareil almond young trees under Nubaria conditions.

\section{Materials and methods \\ Plant materials and treatments}

The present study was conducted during two successive seasons of 2018 and 2019 at the Experimental Research Station of National Research Centre, Nubaria, El Behera governorate, Egypt, on three-year-old Nonpareil almond young trees (Prunus amygdalus B.) budded on bitter almond rootstock and planting space $5 \times 5 \mathrm{~m}$ and grown in sandy soil under drip irrigation system. The soil physical and chemical properties are shown in Table 1. Trees were arranged in randomized complete block design (RCBD), and the following treatments were done with three replicates for each treatment ( 1 replicate $=3$ trees). The experimental treatments were as follow:

1. Control (untreated young trees)

2. $10 \mathrm{~g} /$ young trees humic acid $+10 \mathrm{ml} / \mathrm{l}$ milagro $\odot$

3. $20 \mathrm{~g} /$ young trees humic acid $+10 \mathrm{ml} / \mathrm{l}$ milagro (

4. $30 \mathrm{~g} /$ young trees humic acid $+10 \mathrm{ml} / \mathrm{l}$ milagro $(\mathrm{C}$

5. $10 \mathrm{~g} /$ young trees humic acid $+20 \mathrm{ml} / \mathrm{l}$ milagro $\subset$

6. $20 \mathrm{~g} /$ young trees humic acid $+20 \mathrm{ml} / \mathrm{l}$ milagroc

7. $30 \mathrm{~g} /$ young trees humic acid $+20 \mathrm{ml} / \mathrm{l}$ milagro@

8. $10 \mathrm{~g} /$ young trees humic acid $+30 \mathrm{ml} / \mathrm{l}$ milagro $(\mathrm{C}$

9. $20 \mathrm{~g} /$ young trees humic acid $+30 \mathrm{ml} / \mathrm{l}$ milagro $\subset$

10. $30 \mathrm{~g}$ /young trees humic acid $+30 \mathrm{ml} / \mathrm{l}$ milagro@

All treatments were applied at the beginning of growth season. Humic acid was added to the soil, and milagro

Table 1 Physical and chemical properties of the experimental soil

\begin{tabular}{lllllllll}
\hline Sand (\%) & Silt (\%) & Clay (\%) & Texture & $\mathrm{OM}(\%)$ & $\mathrm{EC} \mathrm{dSm}{ }^{1}$ & $\mathrm{pH}$ & $\mathrm{HCO}^{-3}$ & $\mathrm{CO}^{-3}$ \\
\hline 81.71 & 9.01 & 7.89 & Sandy & 2.84 & 0.54 & 7.88 & 1.7 \\
$\mathbf{C l}^{-}$ & $\mathbf{S O}_{\mathbf{4}}{ }^{-\mathbf{2}}$ & $\mathbf{C a}^{+}$ & $\mathbf{M g}^{+\mathbf{2}}$ & $\mathbf{N a}^{+}$ & $\mathbf{K}^{+}$ & $\mathbf{N}(\%)$ & $\mathbf{P}(\%)$ & $\mathbf{K}(\%)$ \\
3.2 & 0.41 & 2.3 & 2.25 & 0.3 & 0.45 & 0.99 & 0.42 & 0.54 \\
\hline
\end{tabular}


was a foliar application with Tween-20 (0.1\%) as surfactant and applied directly to trees by a handheld sprayer until it runoff in the early morning. Other horticultural practices were carried out as usual. The following parameters were recorded for both seasons.

\section{Vegetative growth measurements}

At mid-August of the two seasons, stem length of young trees $(\mathrm{cm})$ and diameter of young trees $(\mathrm{mm})$, numbers of branches/young trees, numbers of leaves/young trees, leaf fresh weight $(\mathrm{g})$, and leaf dry weight $(\mathrm{g})$ were determined. Leaf area $\left(\mathrm{cm}^{2}\right)$ was measured by using the $\mathrm{Cl}$ 202 portable laser leaf area meter. Specific leaf dry weight (SLDW) $\left(\mathrm{mg} / \mathrm{cm}^{2}\right)$ was determined by the following equation (Yehia, 1994):

$$
\text { Specific leaf dryweight }=\frac{\text { Specific leaf dryweight }(g)}{\text { leaf area }\left(\mathrm{cm}^{2}\right)} \times 1000
$$

\section{Leaf chlorophylls content}

Leave samples were collected at mid-July of each season from the middle portion of the current season growth to each replicate tree to determine chlorophyll-a, chlorophyll-b, and total chlorophyll spectrophotometrically at $645 \mathrm{~nm}$ and $663 \mathrm{~nm}$ wavelengths, respectively, using the method described by (Arnon, 1949).

\section{Leaf minerals content}

Leaf minerals content were determined in leaf samples that were picked in mid-July of each season from the middle portion of the current season growth to each replicate a tree washed and dried at $70^{\circ} \mathrm{C}$ till a constant weight for determination of the following nutrient elements: N, P, K, Mg, Zn, Fe, Mn, and Cu (AOAC, 1985).

\section{Statistical analysis}

The design of the experiment was completely randomized block design with three replicates each consisted of five young trees. All data were subjected to analysis of variance (ANOVA) as described by (Mstat-C, 1989), and the least significant differences (L.S.D) at $5 \%$ were used to compare between treatment means.

\section{Results}

\section{Vegetative growth}

Results in Table 2 showed that the combination between soil application with humic acid and foliar spray of milagro at the different concentrations significantly increased vegetative growth measurements: stem length, diameter, and number of branches and leaves of Nonpareil almond young trees in both seasons of study than the control. In this respect, the treatment with $30 \mathrm{~g}$ humic acid plus 30 $\mathrm{ml} / \mathrm{l}$ milagro gave the highest values of stem length $(110.30$ and $112.6 \mathrm{~cm})$, diameter $(13.00$ and $4.18 \mathrm{~mm})$, number of branches (42.00 and 44.55/young trees), and number of leaves (672.00 and 675.20/young trees ) in the first and second season, respectively, while the lowest values of stem length $(65.33$ and $67.56 \mathrm{~cm})$, diameter (6.50 and $8.09 \mathrm{~mm}$ ), number of branches (4.66 and 6.58/ young trees), and number of leaves (44.00 and 47.75/ young trees) were recorded in the control during the both seasons, respectively.

Means within a column followed by different letter(s) are statistically different at $5 \%$ level

Concerning the leaf area, the results in Table 3 indicated that humic acid soil application and spraying milagro were not significantly influence on the leaf area in both seasons of the study. The values of different treatments ranged between $\left(2.66\right.$ and $\left.3.26 \mathrm{~cm}^{2}\right)$ in the first season and ranged between $\left(2.09\right.$ and $\left.3.53 \mathrm{~cm}^{2}\right)$ in the second season compare with the control which recorded $\left(3.11\right.$ and $\left.3.45 \mathrm{~cm}^{2}\right)$ in the first and second seasons, respectively.

Regarding to the leaf fresh weight, it was increased significantly by treatments. Humic acid $30 \mathrm{~g}$ plus milagro $30 \mathrm{ml} / \mathrm{l}$ gave the highest values of leaf fresh weight (5.40

Table 2 Effect of soil application with humic acid and foliar spray of milagro on stem length, diameter, number of branches and leaves/young trees

\begin{tabular}{|c|c|c|c|c|c|c|c|c|}
\hline \multirow[t]{2}{*}{ Treatments } & \multicolumn{2}{|c|}{ Stem length $(\mathrm{cm})$} & \multicolumn{2}{|c|}{ Stem diameter (mm) } & \multicolumn{2}{|c|}{ No. of branches/young trees } & \multicolumn{2}{|c|}{ No. of leaves/young trees } \\
\hline & 2018 & 2019 & 2018 & 2019 & 2018 & 2019 & 2018 & 2019 \\
\hline Control & $65.33 e$ & $67.56 j$ & $6.50 f$ & $8.09 d$ & 4.66j & $6.58 \mathrm{i}$ & $44.00 j$ & $47.75 j$ \\
\hline $10 \mathrm{~g} \mathrm{H}+10 \mathrm{ml} / \mathrm{l} \mathrm{M}$ & $73.00 d$ & $75.56 \mathrm{~g}$ & 7.00ef & $8.56 \mathrm{~cd}$ & $8.00 \mathrm{~h}$ & $10.22 \mathrm{gh}$ & $56.00 i$ & $59.14 i$ \\
\hline $20 \mathrm{~g} \mathrm{H}+10 \mathrm{ml} / \mathrm{l} \mathrm{M}$ & $78.33 c$ & $80.56 f$ & 8.00de & $9.85 \mathrm{bcd}$ & $7.00 \mathrm{i}$ & $9.56 \mathrm{~h}$ & $63.00 \mathrm{~h}$ & $66.26 \mathrm{~h}$ \\
\hline $30 \mathrm{~g} \mathrm{H}+10 \mathrm{ml} / \mathrm{l} \mathrm{M}$ & $82.00 c$ & $82.56 \mathrm{e}$ & $8.50 d$ & $10.06 \mathrm{bcd}$ & $9.00 \mathrm{~g}$ & $11.36 \mathrm{~g}$ & $77.00 \mathrm{~g}$ & $80.86 \mathrm{~g}$ \\
\hline $10 \mathrm{~g} \mathrm{H}+20 \mathrm{ml} / \mathrm{l} \mathrm{M}$ & $91.00 \mathrm{~b}$ & $89.00 d$ & $10.50 \mathrm{a}$ & $12.12 \mathrm{ab}$ & $11.00 f$ & $13.58 f$ & $105.00 f$ & $108.30 f$ \\
\hline $20 \mathrm{~g} \mathrm{H}+20 \mathrm{ml} / \mathrm{l} \mathrm{M}$ & $70.00 d$ & $70.56 i$ & $9.00 \mathrm{~cd}$ & $10.48 \mathrm{bcd}$ & $15.00 \mathrm{e}$ & $17.45 \mathrm{e}$ & 117.00e & $120.20 \mathrm{e}$ \\
\hline $30 \mathrm{~g} \mathrm{H}+20 \mathrm{ml} / \mathrm{l} \mathrm{M}$ & $72.33 d$ & $74.56 \mathrm{~h}$ & $9.00 \mathrm{~cd}$ & $10.15 b c$ & $22.00 d$ & $24.23 d$ & $160.00 d$ & $163.80 d$ \\
\hline $10 \mathrm{~g} \mathrm{H}+30 \mathrm{ml} / \mathrm{l} \mathrm{M}$ & $91.00 \mathrm{~b}$ & $93.56 \mathrm{c}$ & $10.00 \mathrm{bc}$ & $11.28 \mathrm{bc}$ & $34.00 c$ & $36.27 c$ & $443.00 \mathrm{c}$ & $442.40 \mathrm{c}$ \\
\hline $20 \mathrm{~g} \mathrm{H}+30 \mathrm{ml} / \mathrm{l} \mathrm{M}$ & 107.30a & $109.60 \mathrm{~b}$ & $11.00 \mathrm{~b}$ & $12.37 a b$ & $40.00 \mathrm{~b}$ & $42.12 b$ & $612.00 \mathrm{~b}$ & $615.30 \mathrm{~b}$ \\
\hline $30 \mathrm{~g} \mathrm{H}+30 \mathrm{ml} / \mathrm{l} \mathrm{M}$ & 110.30a & $112.6 a$ & $13.00 a$ & $14.18 \mathrm{a}$ & $42.00 \mathrm{a}$ & $44.55 a$ & $672.00 a$ & $675.20 \mathrm{a}$ \\
\hline
\end{tabular}


Table 3 Effect of soil application with humic acid and foliar spray of milagro on leaf area, leaf fresh weight, leaf dry weight, and specific leaf dry weight

\begin{tabular}{|c|c|c|c|c|c|c|c|c|}
\hline \multirow[t]{2}{*}{ Treatments } & \multicolumn{2}{|c|}{ leaf area $\left(\mathrm{cm}^{2}\right)$} & \multicolumn{2}{|c|}{ leaf fresh weight $(\mathrm{g})$} & \multicolumn{2}{|c|}{ leaf dry weight (g) } & \multicolumn{2}{|c|}{ Specific leaf dry weight $\left(\mathrm{mg} / \mathrm{cm}^{2}\right)$} \\
\hline & 2018 & 2019 & 2018 & 2019 & 2018 & 2019 & 2018 & 2019 \\
\hline Control & $3.11 \mathrm{a}$ & $3.45 a$ & $2.10 \mathrm{c}$ & $2.68 \mathrm{~d}$ & $1.80 \mathrm{~cd}$ & $1.88 \mathrm{c}$ & $578.8 \mathrm{i}$ & $544.93 i$ \\
\hline $10 \mathrm{~g} \mathrm{H}+10 \mathrm{ml} / \mathrm{l} \mathrm{M}$ & $2.66 a$ & $2.93 a$ & $2.10 c$ & $2.68 d$ & $1.80 \mathrm{~cd}$ & $1.83 c$ & $676.7 \mathrm{~h}$ & $624.57 \mathrm{~h}$ \\
\hline $20 \mathrm{~g} \mathrm{H}+10 \mathrm{ml} / \mathrm{l} \mathrm{M}$ & $2.82 \mathrm{a}$ & $2.09 a$ & $2.40 \mathrm{c}$ & $2.98 \mathrm{~cd}$ & $1.50 \mathrm{~d}$ & $1.33 d$ & $531.9 j$ & $636.36 \mathrm{~g}$ \\
\hline $30 \mathrm{~g} \mathrm{H}+10 \mathrm{ml} / \mathrm{l} \mathrm{M}$ & $2.93 a$ & $3.20 \mathrm{a}$ & $3.20 \mathrm{bc}$ & $3.78 c$ & $2.30 \mathrm{bcd}$ & $3.13 a b$ & 785.0f & $978.13 a$ \\
\hline $10 \mathrm{~g} \mathrm{H}+20 \mathrm{ml} / \mathrm{l} \mathrm{M}$ & $3.01 \mathrm{a}$ & $3.28 \mathrm{a}$ & $3.20 b c$ & $3.78 \mathrm{c}$ & $2.30 \mathrm{bcd}$ & $3.13 a b$ & $764.1 \mathrm{~g}$ & $954.27 \mathrm{~b}$ \\
\hline $20 \mathrm{~g} \mathrm{H}+20 \mathrm{ml} / \mathrm{l} \mathrm{M}$ & $2.57 a$ & $2.84 a$ & $3.40 \mathrm{bc}$ & $3.98 b$ & $2.51 b c$ & $2.33 c$ & $972.8 \mathrm{C}$ & $820.42 \mathrm{e}$ \\
\hline $30 \mathrm{~g} \mathrm{H}+20 \mathrm{ml} / \mathrm{l} \mathrm{M}$ & $2.91 \mathrm{a}$ & $3.18 \mathrm{a}$ & $4.00 \mathrm{ab}$ & $3.58 d$ & $2.80 \mathrm{ab}$ & $2.63 b$ & $962.2 d$ & 827.04e \\
\hline $10 \mathrm{~g} \mathrm{H}+30 \mathrm{ml} / \mathrm{l} \mathrm{M}$ & $2.78 \mathrm{a}$ & $3.05 \mathrm{a}$ & 4.10ab & $3.68 d$ & $2.40 \mathrm{bcd}$ & $2.23 c$ & 863.3e & $731.15 f$ \\
\hline $20 \mathrm{~g} \mathrm{H}+30 \mathrm{ml} / \mathrm{l} \mathrm{M}$ & $3.26 \mathrm{a}$ & $3.53 a$ & $5.10 \mathrm{a}$ & $3.68 d$ & $3.20 \mathrm{ab}$ & $3.03 b$ & $981.6 b$ & $858.36 d$ \\
\hline $30 \mathrm{~g} \mathrm{H}+30 \mathrm{ml} / \mathrm{l} \mathrm{M}$ & $3.11 \mathrm{a}$ & 3.38a & $5.40 a$ & $4.98 a$ & $3.60 a$ & $3.16 a$ & 1158.0a & $934.91 \mathrm{C}$ \\
\hline
\end{tabular}

and $4.98 \mathrm{~g}$ ) in the first and second season, respectively, while the lowest values ( 2.10 and $2.68 \mathrm{~g})$ were recorded in the control during the both seasons, respectively (Table 3).

Table 3 clears that leaf dry weight was significantly increased by treatment with humic acid and milagro. The highest significant leaf dry weight (3.60 and $3.16 \mathrm{~g}$ ) obtained in young trees is treated with humic acid $30 \mathrm{~g}$ plus milagro $30 \mathrm{ml} / \mathrm{l}$ in both seasons, respectively, while the lowest significant leaf dry weight (1.50 and $1.33 \mathrm{~g}$ ) obtained in young trees is treated with humic acid $20 \mathrm{~g}$ plus milagro $10 \mathrm{ml} / \mathrm{l}$ during seasons 2018 and 2019, respectively.

Specific leaf dry weight was significantly affected by soil application with humic acid and foliar spray of milagro (Table 3). In the first season, the highest value of specific leaf dry weight $(1158 \mathrm{mg} / \mathrm{cm} 2)$ was obtained by humic acid $30 \mathrm{~g}$ plus milagro $30 \mathrm{ml} / \mathrm{l}$, while the lowest value $\left(531.9 \mathrm{mg} / \mathrm{cm}^{2}\right)$ was obtained by humic acid $20 \mathrm{~g}$ plus milagro $10 \mathrm{ml} / \mathrm{l}$. In the second season, the highest value of

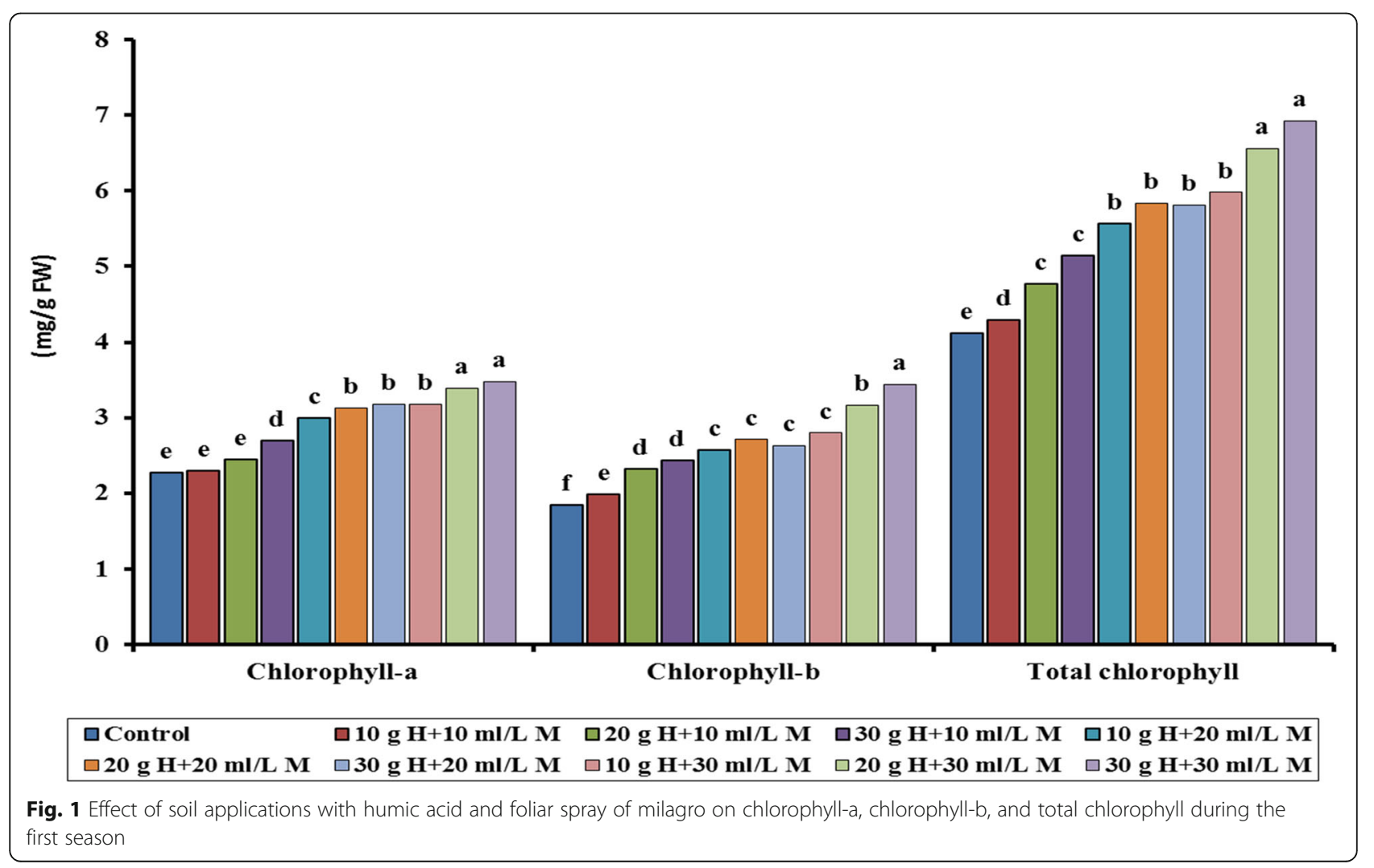


specific leaf dry weight $\left(978.13 \mathrm{mg} / \mathrm{cm}^{2}\right)$ was obtained by humic acid $20 \mathrm{~g}$ plus milagro $10 \mathrm{ml} / \mathrm{l}$, while the lowest value $\left(544.93 \mathrm{mg} / \mathrm{cm}^{2}\right)$ was recorded in the control.

Means within a column followed by different letter(s) are statistically different at $5 \%$ level

\section{Leaf chlorophylls content}

Figures 1 and 2 present the effect of soil application with humic acid and foliar spray of milagro at the different concentrations on leaf chlorophylls content of Nonpareil almond young trees during the two seasons. All treatments improved leaf content of chlorophyll-a, chlorophyll-b, and total chlorophyll $(\mathrm{a}+\mathrm{b})$ compared with control which recorded the lowest values $(2.27,1.85$, and $4.12 \mathrm{mg} / \mathrm{g} \mathrm{FW})$ in the first season and $(2.30,1.84$, and $4.14 \mathrm{mg} / \mathrm{g} \mathrm{FW})$ in the second season, respectively.

Results of the 2 years pointed out that there was a clear variation among treatments with the same trend for improving the chlorophyll-a, chlorophyll-b, and total chlorophyll $(\mathrm{a}+\mathrm{b})$, where the young trees treated with $30 \mathrm{~g}$ humic acid plus $30 \mathrm{ml} / \mathrm{l}$ milagro recorded the highest values (3.48, 3.44, and $6.92 \mathrm{mg} / \mathrm{g} \mathrm{FW)} \mathrm{and} \mathrm{(3.60,} \mathrm{3.45,}$ and $7.05 \mathrm{mg} / \mathrm{g} \mathrm{FW}$ ) in both seasons, respectively, followed by treatment with humic acid $20 \mathrm{~g}$ plus milagro $30 \mathrm{ml} / \mathrm{l}$ which gave significant similar results and came in the second arrangement for its impact on improving chlorophyll-a, chlorophyll-b, and total chlorophyll ranged from $(3.39,3.17$, and $6.56 \mathrm{mg} / \mathrm{g} F W)$ in the 1 st season and $(3.55,3.18$, and $6.73 \mathrm{mg} / \mathrm{g} \mathrm{FW})$ in the 2nd season, respectively.

\section{Leaf minerals content}

As for the effect of soil application with humic acid and foliar spray of milagro on some leaf macro element contents, the results in Table 4 presented that the treatments influenced significantly on $\mathrm{N}, \mathrm{P}, \mathrm{K}$, and Mg leaf contents of Nonpareil almond young trees than the control in both seasons. Regarding to leaf $\mathrm{N}$ and $\mathrm{K}$ contents, the results showed that the soil applications with humic acid and foliar spray of milagro at the different concentrations gave higher content than the control. The highest values of leaf $\mathrm{N}$ and $\mathrm{K}$ contents $(2.40$ and 2.79 and 3.18 and $3.36 \%$ ) were recorded by $30 \mathrm{~g}$ humic acid plus $30 \mathrm{ml} / \mathrm{l}$ milagro in 1st and 2nd seasons, respectively, while the lowest value of leaf $\mathrm{N}$ content (1.05 and 1.14 and 2.30 and $1.70 \%$ ) was recorded in the control in 1 st and 2nd seasons, respectively.

Concerning leaf $\mathrm{P}$ content, the treatment with $30 \mathrm{~g}$ humic acid plus $30 \mathrm{ml} / \mathrm{l}$ milagro recorded the highest significant value of leaf $\mathrm{P}$ content (1.89 and $1.88 \%$ ) in

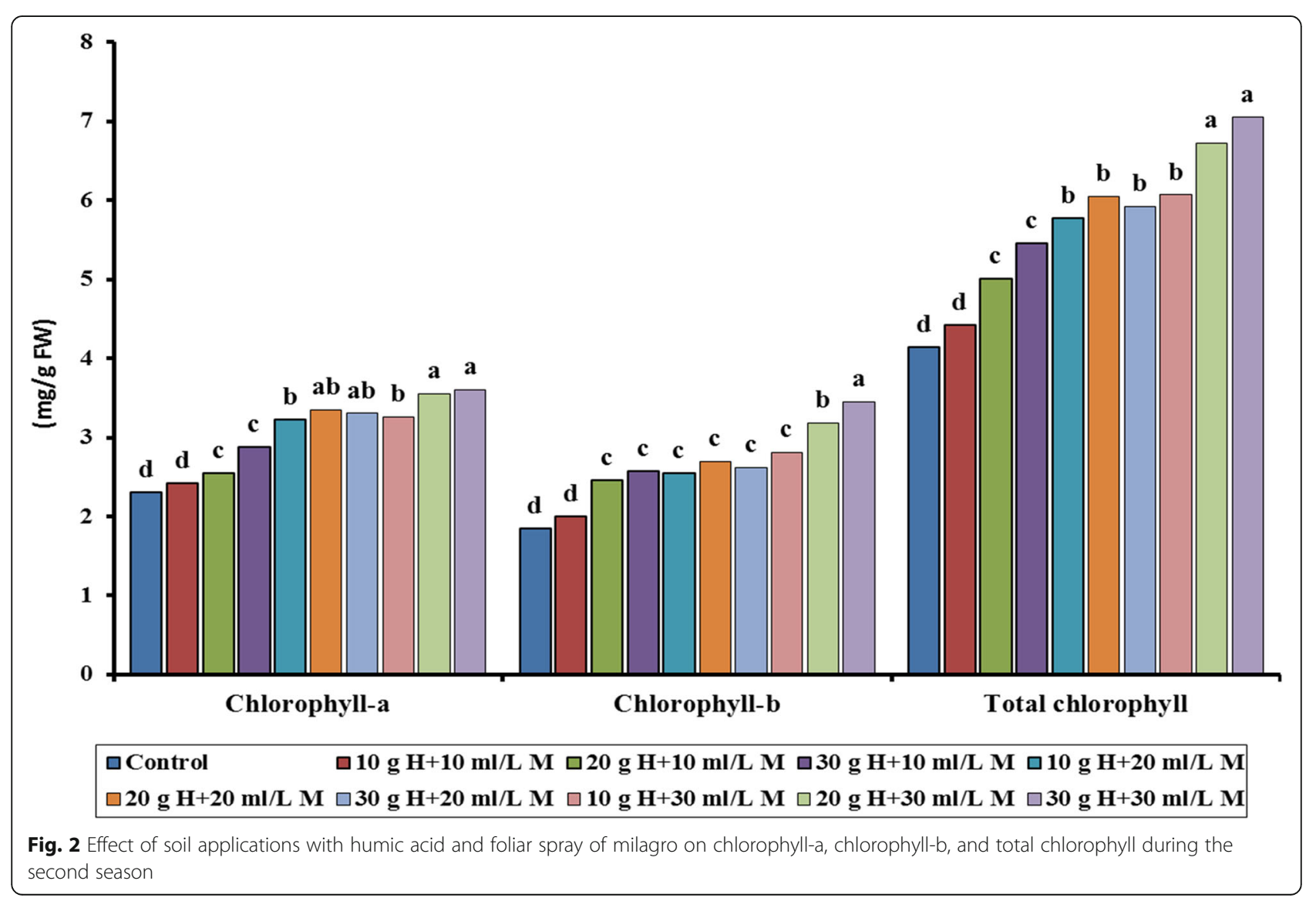


Table 4 Effect of soil application with humic acid and foliar spray of milagro on some leaf macro element contents

\begin{tabular}{|c|c|c|c|c|c|c|c|c|}
\hline \multirow[t]{2}{*}{ Treatments } & \multicolumn{2}{|c|}{ Nitrogen (\%) } & \multicolumn{2}{|c|}{ Phosphorus (\%) } & \multicolumn{2}{|c|}{ Potassium (\%) } & \multicolumn{2}{|c|}{ Magnesium (\%) } \\
\hline & 2018 & 2019 & 2018 & 2019 & 2018 & 2019 & 2018 & 2019 \\
\hline Control & $1.05 \mathrm{~d}$ & $1.14 d$ & $1.47 \mathrm{bc}$ & $1.46 b$ & $2.30 \mathrm{~cd}$ & $1.70 \mathrm{~b}$ & $0.28 \mathrm{c}$ & $0.36 a$ \\
\hline $10 \mathrm{~g} \mathrm{H}+10 \mathrm{ml} / \mathrm{l} \mathrm{M}$ & $1.93 a b$ & $2.32 \mathrm{ab}$ & $1.53 b c$ & $1.52 \mathrm{ab}$ & $2.65 a b c$ & $2.83 a b$ & $0.48 \mathrm{a}$ & $0.56 a$ \\
\hline $20 \mathrm{~g} \mathrm{H}+10 \mathrm{ml} / \mathrm{l} \mathrm{M}$ & $1.73 b c$ & $2.12 a b c$ & $1.70 a b$ & 1.69ab & $2.85 \mathrm{de}$ & $2.03 a b$ & $0.30 b c$ & $0.58 a$ \\
\hline $30 \mathrm{~g} \mathrm{H}+10 \mathrm{ml} / \mathrm{l} \mathrm{M}$ & $1.63 \mathrm{bc}$ & $2.02 a b c$ & $1.89 a$ & $1.88 \mathrm{a}$ & $2.73 a b c$ & $2.91 a b$ & $0.46 a$ & $0.54 a$ \\
\hline $10 \mathrm{~g} \mathrm{H}+20 \mathrm{ml} / \mathrm{l} \mathrm{M}$ & $1.10 \mathrm{~d}$ & $1.44 \mathrm{~cd}$ & $1.60 a b c$ & $1.56 a b$ & $2.44 b c$ & $2.61 a b$ & $0.42 a b$ & $0.50 \mathrm{a}$ \\
\hline $20 \mathrm{~g} \mathrm{H}+20 \mathrm{ml} / \mathrm{l} \mathrm{M}$ & $1.28 \mathrm{~cd}$ & $1.67 \mathrm{bcd}$ & $1.60 a b c$ & $1.59 a b$ & $2.53 \mathrm{ef}$ & $1.71 b$ & $0.50 \mathrm{a}$ & $0.58 a$ \\
\hline $30 \mathrm{~g} \mathrm{H}+20 \mathrm{ml} / \mathrm{l} \mathrm{M}$ & $1.12 \mathrm{~d}$ & $1.49 \mathrm{~cd}$ & $1.60 a b c$ & $1.59 a b$ & $2.50 f$ & $2.61 a b$ & $0.30 b c$ & $0.48 a$ \\
\hline $10 \mathrm{~g} \mathrm{H}+30 \mathrm{ml} / \mathrm{l} \mathrm{M}$ & $1.06 \mathrm{~d}$ & $1.47 \mathrm{~cd}$ & $1.73 a b$ & $1.72 a b$ & $2.43 b c$ & $2.48 \mathrm{ab}$ & $0.50 \mathrm{a}$ & $0.53 a$ \\
\hline $20 \mathrm{~g} \mathrm{H}+30 \mathrm{ml} / \mathrm{l} \mathrm{M}$ & $1.28 \mathrm{~cd}$ & $1.67 \mathrm{bcd}$ & $1.78 a b$ & $1.77 a b$ & $2.95 a b$ & $3.13 a b$ & $0.45 \mathrm{a}$ & $0.53 a$ \\
\hline $30 \mathrm{~g} \mathrm{H}+30 \mathrm{ml} / \mathrm{l} \mathrm{M}$ & $2.40 a$ & $2.79 a$ & $1.61 a b c$ & 1.60ab & $3.18 \mathrm{a}$ & $3.36 a$ & $0.52 \mathrm{a}$ & $0.58 a$ \\
\hline
\end{tabular}

both seasons, respectively, while the other treatments lacked significance between them in both seasons (Table 4). Meanwhile, the control gave the lowest significant value of leaf $\mathrm{P}$ content (1.47 and 1.46\%) in both seasons, respectively.

Regarding leaf $\mathrm{Mg}$ content, Table 4 explained that it was increased by all treatments than the control which was the lowest content during the two seasons of this study. Also, the analysis of variance at the $5 \%$ level showed that the leaf $\mathrm{Mg}$ content was slightly higher significant in the first season, while the leaf $\mathrm{Mg}$ content was not significantly differ between the different treatments in the second season.

Table 5 presented the effect of soil application with humic acid and foliar spray of milagro on some leaf micro elements of Nonpareil almond young trees during two seasons. In this respect, the treatments influenced significantly on $\mathrm{Zn}, \mathrm{Fe}, \mathrm{Mn}$, and $\mathrm{Cu}$ leaf contents than the control in both seasons. Regarding to the leaf $\mathrm{Zn}$ content, the results showed that the treatment with humic acid $20 \mathrm{~g}$ plus milagro $20 \mathrm{ml} / \mathrm{l}$ gave the highest values (47.67 and $49.21 \mathrm{ppm}$ ) in 1st season and 2nd season, respectively.
Concerning to leaf $\mathrm{Fe}, \mathrm{Mn}$, and $\mathrm{Cu}$, contents, the treatment with humic acid $30 \mathrm{~g}$ plus milagro $30 \mathrm{ml} / \mathrm{l}$ gave the highest significant values (129.90 and $131.85 \mathrm{ppm})$, (80.04 and 81.34 ppm), and (48.38 and 46.84 ppm) in 1st season and 2nd season, respectively.

Meanwhile, the control recorded the lowest significant values of leaf $\mathrm{Zn}, \mathrm{Fe}, \mathrm{Mn}$, and $\mathrm{Cu}$ contents in the both seasons.

Means within a column followed by different letter(s) are statistically different at $5 \%$ level

Means within a column followed by different letter(s) are statistically different at $5 \%$ level

\section{Discussions}

The obtained results cleared that the beneficial effect of combination between soil application with humic acid and foliar spray of milagro at the different concentrations on increasing the uptake of different nutrients and availability of soil nutrients particularly in sandy soil under Nubaria conditions, especially when applied humic acid soil application and spray milagro at high rate $30 \mathrm{~g}$ plus $30 \mathrm{ml} / \mathrm{l}$. This explains the improving nutrient status in Tables 4

Table 5 Effect of soil application with humic acid and foliar spray of milagro on some leaf micro element contents

\begin{tabular}{|c|c|c|c|c|c|c|c|c|}
\hline \multirow[t]{2}{*}{ Treatments } & \multicolumn{2}{|c|}{ Zinc (ppm) } & \multicolumn{2}{|c|}{ Iron (ppm) } & \multicolumn{2}{|c|}{ Manganese (ppm) } & \multicolumn{2}{|c|}{ Copper (ppm) } \\
\hline & 2018 & 2019 & 2018 & 2019 & 2018 & 2019 & 2018 & 2019 \\
\hline Control & $20.00 \mathrm{~g}$ & $20.00 e$ & $100.00 f$ & 100.00e & $20.00 \mathrm{~g}$ & $21.00 i$ & $20.00 f$ & $31.63 c$ \\
\hline $10 \mathrm{~g} \mathrm{H}+10 \mathrm{ml} / \mathrm{l} \mathrm{M}$ & 28.97e & $30.51 d$ & 128.08ab & 128.86ab & $50.46 b c$ & $51.76 c$ & 35.48de & $32.53 c$ \\
\hline $20 \mathrm{~g} \mathrm{H}+10 \mathrm{ml} / \mathrm{l} \mathrm{M}$ & $20.47 \mathrm{fg}$ & $22.01 \mathrm{e}$ & 105.98e & $107.93 d$ & $22.62 f$ & $23.92 f$ & 35.48de & $33.20 c$ \\
\hline $30 \mathrm{~g} \mathrm{H}+10 \mathrm{ml} / \mathrm{l} \mathrm{M}$ & $32.74 d$ & $34.28 \mathrm{~cd}$ & $114.95 d$ & $116.90 \mathrm{c}$ & $43.50 \mathrm{~cd}$ & 44.80e & $45.80 \mathrm{ab}$ & $35.85 b c$ \\
\hline $10 \mathrm{~g} \mathrm{H}+20 \mathrm{ml} / \mathrm{l} \mathrm{M}$ & $44.07 b$ & $45.61 b$ & $120.93 c$ & $122.88 \mathrm{bc}$ & 34.80de & $36.10 f$ & $40.64 \mathrm{bcd}$ & $38.69 b$ \\
\hline $20 \mathrm{~g} \mathrm{H}+20 \mathrm{ml} / \mathrm{l} \mathrm{M}$ & $47.67 a$ & $49.21 a$ & $123.92 b c$ & $125.87 a b$ & $59.16 b$ & $60.46 b$ & $43.22 a b c$ & $36.43 b c$ \\
\hline $30 \mathrm{~g} \mathrm{H}+20 \mathrm{ml} / \mathrm{l} \mathrm{M}$ & $36.05 c$ & $37.59 c$ & $101.00 f$ & 101.00e & $60.9 b$ & $62.20 \mathrm{~b}$ & $38.06 \mathrm{cde}$ & $30.00 d$ \\
\hline $10 \mathrm{~g} \mathrm{H}+30 \mathrm{ml} / \mathrm{l} \mathrm{M}$ & $34.16 d$ & $35.70 \mathrm{~cd}$ & $123.92 \mathrm{bc}$ & $125.87 a b$ & $46.98 c$ & $48.28 \mathrm{~d}$ & $32.90 \mathrm{e}$ & $32.40 \mathrm{c}$ \\
\hline $20 \mathrm{~g} \mathrm{H}+30 \mathrm{ml} / \mathrm{l} \mathrm{M}$ & $31.88 f$ & $23.42 e$ & $114.95 d$ & $116.90 \mathrm{c}$ & 31.32ef & $32.62 \mathrm{~g}$ & $40.64 \mathrm{bcd}$ & $36.80 \mathrm{bc}$ \\
\hline $30 \mathrm{~g} \mathrm{H}+30 \mathrm{ml} / \mathrm{l} \mathrm{M}$ & $34.10 d$ & $36.64 \mathrm{~cd}$ & 129.90a & $131.85 a$ & $80.04 a$ & $81.34 a$ & $48.38 a$ & $46.84 a$ \\
\hline
\end{tabular}


and 5 and leaf chlorophylls content in Figs. 1 and 2 of Nonpareil almond young trees s that reflected on increasing the vegetative growth (Tables 2 and 3 ).

Increases in vegetative growth can be attributed to the positive effect of humic acid on both plants and soil in increasing microbial activity and enhance soil effectiveness in nutrient uptake as chelating agent and biostimulation of plant growth which improves vegetative characteristics, nutritional status, and leaf pigments. These results are in harmony with those obtained by (Mustafa and El-Shazly, 2013; Fatma et al. 2015; Eisa et al. 2016) who reported that application of humic acid resulted in increment of plant height, lateral shoot number per plant, leaves number per plant, stem diameter, leaf area, dry weight, and total leaf chlorophyll content comparing with the control.

The simulative effect of humic acid on nutrients concentrations might be explained that humic acid enhanced cell permeability, which in turn made more rapid entry of minerals into root cells and so resulted in higher uptake of plant nutrients and promoted the accumulation $(\mathrm{N}, \mathrm{P}, \mathrm{K}$, and $\mathrm{Mg}$ ) in leaves than the untreated ones. On the other hand, the least growth in the control was probably due to nutrition status deficiency which could probably reduce number of functional leaves and subsequently the photosynthetic efficiency. This observation is in agreement with the findings of (Stefano et al. 2004) who reported that number of leaves per plant was dependent on fertilizer rate as it increased with increasing fertilizer rate. These results are also in harmony with (Fathy et al. 2010; El- Khawaga, 2011; Tahira et al. 2013; Abd El-Razek et al. 2018). Furthermore, the effects of humic acid on increasing $\mathrm{Fe}$ and $\mathrm{Zn}$ concentrations in the leaves might be due to their effect on the reduction of $\mathrm{Fe}^{3+}$ to $\mathrm{Fe}^{2+}$, making iron chelates that are readily available to the plants and prevent the formation of insoluble complexes of $\mathrm{Fe}, \mathrm{Zn}$, and $\mathrm{Mn}$ and facilitated their uptake by plants. These results conformed to those obtained by (Gregor and Powerll, 1988; Chen and Aviad, 1990; Eisa et al. 2016).

Also, the increases can be referred in the vegetative growth and nutritional status resulting by foliar application of milagro to its content of many growth regulators. This compound combines the effects of auxins, cytokinins, gibberellic acid, and ethylene; when applied at the growth stage, it combines as the effect of cytokinins (cell division) and gibberellic acid (elongation cell) especially in the meristematic tissues. In addition, milagro provides all the nutrients needed by the plant in the stages of root growth which can give an explanation for improving on growth characteristics and nutritional status of Nonpareil almond young trees. These results are in agreement with those obtained by (Omaima et al. 2014; Abou El Magd et al. 2018).

\section{Conclusion}

It can be concluded that the foliar spray of natural biostimulant milagro at $30 \mathrm{ml} / \mathrm{l}$ combined with soil application of humic acid at $30 \mathrm{~g} /$ young trees as a new fertilization technique is non-chemical for improving growth and nutritional status of Nonpareil almond young trees under Nubaria conditions. Besides, its effect is environmentally safe and low-cost.

\section{Abbreviations}

H: Humic acid; M: Milagro; SLDW: Specific leaf dry weight

\section{Acknowledgements}

Authors would like to express their gratitude for the National Research Centre (NRC), Egypt, for supporting and offering generous funding for the project "echnology of cultivating some promising fruit trees under sandy soil conditions of Nubaria."

\section{Authors' contributions}

This work was carried out in collaboration between all authors. NEK designed this study and wrote the protocol. ERA and OAA applied the field works, following up the growth of almond young trees, collected samples, and measured its physical measurements. AMR performed the chemical analysis of the samples and the statistical analysis. TSMM prepared the samples for analysis, managed the analyses of the study and the literature searches, and wrote the first draft of the manuscript. AMS consulted the study design, protocol, and treatments and reviewed the manuscript. All authors read and approved the final version.

\section{Authors' information}

Dr. Amal Masoad Rakha is a researcher at the Department of Horticultural Crops Technology, Agricultural and Biological Division, National Research Center, Dokki, Giza, Egypt.

Dr. Thanaa Shaban Mohamed Mahmoud is an associate professor at the Department of Horticultural Crops Technology, Agricultural and Biological Division, National Research Center, Dokki, Giza, Egypt.

Dr. Ramadan Ahmed Eisa is an associate professor at the Department of Horticultural Crops Technology, Agricultural and Biological Division, National Research Center, Dokki, Giza, Egypt.

Dr. Osama Abdelfattah Amin is an associate professor at the Department of Horticultural Crops Technology, Agricultural and Biological Division, National Research Center, Dokki, Giza, Egypt.

Dr. Nabila Elbadawy Kaseem is a professor at the Department of Horticultural Crops Technology, Agricultural and Biological Division, National Research Center, Dokki, Giza, Egypt.

Dr. Mahmoud Sami Abourayya is a professor at the Department of Horticultural Crops Technology, Agricultural and Biological Division, National Research Center, Dokki, Giza, Egypt.

\section{Funding}

This work was supported and funded by the National Research Centre through the project titled Technology of cultivating some promising fruit trees under sandy soil conditions of Nubaria. Project ID 11030146, during $2016 / 2019$.

\section{Availability of data and materials}

The datasets generated and/or analyzed during the current study are included in this published.

Ethics approval and consent to participate

Not applicable

Consent for publication

Not applicable

Competing interests

The authors declare that they have no competing interests. 
Received: 10 January 2020 Accepted: 4 March 2020

Published online: 16 March 2020

\section{References}

Abd El-Razek E, Haggag LF, MMM A-E-M, El-Hady Combined ES (2018) Effects of soil applications of humic acid and foliar spray of amino acids on yield and fruit quality of 'Florida Prince' peach trees under calcareous soil conditions. Bioscience Research 15:3270-3282

Abou El Magd MM, Zaki MF, Abo Sedera SA. Bio-fertilization and foliar application of milagro bio-stimulant in relation to growth, head yield and quality as well as mineral K requirements of Chinese. 2018

Abou Rayya MSM, Kasim NE, Shaheen MA, Yehia TA, Ali EL (2009) Morphological and anatomical evaluation of different budding and grafting methods and times of Neplus ultra almond cultivar. Journal of Applied Sciences Research. 5:253-262

AOAC. Official methods of analysis. Association of fficial Agricultural Chemists, $14^{\text {th }}$ ed: Benjamin Farnklin station Washington, Dc, USA. 1985: 490-510

Arnon DI (1949) Copper enzyme polyphenoloxides in isolated chloroplast in Beta vulgaris. Plant Physiology. 24:1-15

Aslanta R, Guleryuz M, Tarun M. Some chemical contents of selected almond (Prunus amygdalus Batsch) types in 11 GREMPA Seminar on Pistachios and Almonds, B. E. Ak, Ed., vol. 56 of Cahiers Options Mediterraneennes. 2001: 347-350.

Chen Y, Aviad T (1990) Effect of humic substances on plant growth. In: Humic substances in soil and crop sciences: American Society of Agronomy and Soil Science::161-186

Chen $\mathrm{Y}$, Magen $\mathrm{H}$, Riov J. Humic substances originating from rapidly decomposing organic matter. Proc Int Meet 1994: 427- 443 (Chem Abst 121: 229)

Chunhua L, Cooper RJ, Bowman DC (1998) Humic acid application affects photosynthesis, root development and nutrient content of creeping bentgrass. Hort Sci 33:1023-1025

Ebeed S, Mostafa EAM, Saleh MMS (2008) Effect of gibberellic acid and male bud removal on yield and fruit quality of banana plants. Res J Agric Biol Sci. 4: 289-292

Eisa RA, Thanaa SM, Nabila EK, Abou Rayya MS (2016) Foliar application of lowbiuret urea and humic acid influences on the growth and leaf mineral composition of Nonpareil almond young trees s under South Sinai conditions. Journal of Innovations in Pharmaceuticals and Biological Sciences. 3:143-153

Fathy MA, Gabr MA, El Shall SA (2010) Effect of humic acid treatments on 'Canino' apricot growth, yield and fruit quality. New York Sci J. 3:109-115

Fatma KM, Shaaban MMM, Mahmoud TSM (2015) Influence of spraying yeast extract and humic acid on fruit maturity stage and storability of "Canino" apricot fruits. International Journal of ChemTech Research 8:530-543

Gregor JE, Powerll HKJ (1988) Protonation reactions of fulvic acids. Journal Soil Science. 39:243-252

Grove MD, Spencer GF (1979) Rohwedder WK. Brassinolide, a plant growth promoting steroid isolated from Brassica napus pollen Nature. 281:216-217

Kasim NE, Abou Rayya MSM, Shaheen MA, Yehia TA, Ali EL (2009) Effect of different collection times and some treatments on rooting and chemical internal constituents of bitter almond hardwood cuttings. Research Journal of Agriculture and Biological Sciences. 5:116-122

Khattab MM, Shaban AE, El-Shrief AH, Mohamed AS (2012) Effect of humic acid and amino acids on pomegranate trees under deficit irrigation. I: Growth, flowering and fruiting. J Hort Sci\& Ornam Plants. 4:253-259

Ladizinsky G (1999) On the origin of almond. Genetic Resources and Crop Evolution 46:143-147

Mstat C (1989) Users guide: a micro-computer program for the design, management and analysis of agronomic research experiments. Michigan University, East Lansing, Mc, USA

Mustafa NS, El-Shazly SM (2013) Impact of some biostimulant substances on growth parameters of Washington Navel orange trees. Middle East J of Appl Sci. 3:156-160

O'Donnell RW (1973) The auxin-like effects of humic preparations from leonardite. Soil Sci 116:106-112

Omaima MH, Malaka A Saleh, Mostafa EAM, El-Shamma MS, Maksoudd MA Improving pollination efficiency, yield and fruit quality of two date palm cultivars using growth activator. International Journal of Agricultural Research. 2014; 9 : 29-37.
Ramezani S, Shekafandeh A (2009) Roles of gibberellic acid and zinc sulphate in increasing size and weight of olive fruit. Afr J Biotechnol. 8:6791-6794

Russo RO, Berlyn GP (1990) The use of organic biostimulants to help low input sustainable agriculture. J Sustainable Agric. 1:9-42

Senn TL, Kingman AR. A review of humus and humic acids. www. australianhumates.com. 2000;1 - 5 .

Stefano P, Dris R, Rapparini F (2004) Influence of growing conditions and yield and quality of cherry. II. Fruit Journal of Agricultural and Environment. 2:307309

Tahira A, Ahmed S, Ashrsaf M, Shadhid MA, Yasin M, Balal RM (2013) Pervez MA Abbas. Effect of humic application at different growth stages of Kinnow mandarin (Citrus recticulatablanco) on the basis of physio-biochemical and reproductive responses. Academia Journal of Biotechnology. 1:14-20

Yehia TA Characterization and prediction of flowering in apples. Ph. D. Thesis, Nottingham University. 1994; UK, 274 p.

\section{Publisher's Note}

Springer Nature remains neutral with regard to jurisdictional claims in published maps and institutional affiliations.

\section{Submit your manuscript to a SpringerOpen ${ }^{\circ}$ journal and benefit from:}

- Convenient online submission

- Rigorous peer review

- Open access: articles freely available online

- High visibility within the field

- Retaining the copyright to your article

Submit your next manuscript at $\boldsymbol{\nabla}$ springeropen.com 